\title{
Genetic Polymorphisms of Osteopontin in Association with Ankylosing Spondylitis in a Chinese Population
}

\author{
Xiu-fang Wang and Yi Cai* \\ Department of Pain, The Central Hospital of Wuhan, Wuhan, Hubei Province, 430021, China
}

${ }^{*}$ For correspondence: Email: 187076605@qq.com

Received: 7 August 2015

Revised accepted: 5 November 2015

\begin{abstract}
Purpose: To determine the association of osteopontin (OPN) polymorphisms with ankylosing spondylitis (AS).

Methods: A total of 120 cases diagnosed with AS and 106 age- and sex-matched healthy controls were recruited. All the patients were human leukocyte antigen (HLA)-B27 positive. Three single nucleotide polymorphisms were genotyped using direct sequencing

Results: The T allele at -443 SNP had significantly higher frequency in AS patients (0.1875) than the controls $(0.1085, p<0.01)$. The rate of CT+TT genotype in AS patients was significantly higher than those with CC genotype compared with the control $(p<0.01)$.

Conclusion: SNP at -443 of OPN gene can serve as a candidate genetic marker to evaluate the risk of $A S$, thus indicating that subjects who carry $T$ allele have a significantly higher risk of developing AS.
\end{abstract}

Keywords: Genetic polymorphism, Ankylosing spondylitis, Osteopontin, Sequencing

Tropical Journal of Pharmaceutical Research is indexed by Science Citation Index (SciSearch), Scopus, International Pharmaceutical Abstract, Chemical Abstracts, Embase, Index Copernicus, EBSCO, African Index Medicus, JournalSeek, Journal Citation Reports/Science Edition, Directory of Open Access Journals (DOAJ), African Journal Online, Bioline International, Open-J-Gate and Pharmacy Abstracts

\section{INTRODUCTION}

Ankylosing spondylitis (AS) is a chronic inflammatory disorder characterized by inflammation in the spine and sacroiliac joints causing initial bone and joint erosion and subsequent ankylosis [1]. Most patients develop first symptoms of AS younger than 30 years of age [2]. More recent studies have shown that structural damage at initial presentation is the best predictor of further damage [3-5].

Osteopontin (OPN) is well known as a major non-collagenous protein related to bone remodeling [6-7].The expression of OPN in different cell types was significantly influenced by transcription factors, and the genetic polymorphisms of the promoter [8]. Previous studies showed that OPN inhibited nucleation, growth, and aggregation of calcium oxalate crystals in vitro $[9,10]$, and was able to directly inhibit the binding of calcium oxalate crystals to cultured renal epithelial cells [11]. Therefore, OPN is an important modulator of stone formation. Mutations in the gene directing the synthesis of OPN may predispose to AS.

Recently, -443T/C polymorphisms on the promoter region of OPN gene have been found to affect gene expression and transcriptional activity [12,13], and have been found to associate with several diseases, including pseudoxanthoma elasticum [14], stroke [15], and chronic hepatitis C [16]. The -443 T/C polymorphism influenced the binding of MYT1 zinc finger factor, which is associated with neurogenesis [17]. In chronic hepatitis C 
patients, the $-443 \mathrm{~T} / \mathrm{C}$ polymorphism could be a marker reflecting hepatitis activity [18].

AS patients' disease severity is largely genetically determined [19]. However, there are no relative reports about the relationship between OPN polymorphisms and risk of AS currently. Previous study confirmed that OPN is overexpressed and with higher levels in AS patients compared with controls $[20,21]$. However, there have been no studies investigated the association of polymorphisms of OPN gene with AS to date. Therefore, we conducted a hospital-based case-control study to investigate the association of polymorphisms of OPN gene with the risk of AS in a Chinese population.

\section{EXPERIMENTAL}

\section{Subjects}

A case-control study was conducted between May 2010 and October 2012. A total of 120 unrelated AS patients included 78 men and 42 women with mean age of $39.5 \pm 10.3$ years (range 18-52 years, all the patients were HLAB27 positive) and 106 normal control included 71 men and 35 women with mean age of $35.8 \pm$ 11.5 years (range 15 - 48 years). All the subjects were recruited after giving written informed consent. This study was approved by Ethics Committee of Autonomous Region People's Hospital (approval ref. no. 20100301) [22].

\section{Analysis of OPN gene polymorphisms}

Three milliliters of fasting venous blood were collected from all subjects. Genomic DNA was extracted from the white blood cells following standard protocols. SNP was determined using direct sequencing of the sense and anti-sense strands following polymerase chain reaction (PCR) amplification of the promoter regulatory region -532 to +94 . PCR was performed using 50 ng DNA as a template under the following conditions: $94^{\circ} \mathrm{C}$ for $7 \mathrm{~min}$, then 30 cycles of 94 ${ }^{\circ} \mathrm{C}$ for $55 \mathrm{~s}$, an annealing temperature for $50 \mathrm{~s}$ and $72{ }^{\circ} \mathrm{C}$ for $90 \mathrm{~s}$, with a final extension at $72^{\circ} \mathrm{C}$ for $10 \mathrm{~min}$. The PCR products were subjected to cycle sequencing with the respective forward and reverse primer using an automated $A B I 3100$ DNA sequencer by GeneCore Bio Technologies (Shanghai, China).

\section{Statistical analysis}

Statistical analysis was performed using SPSS 11.5 software. One-way ANOVA and t-test were used to compare mean differences for continuous variables. Allele frequency was determined via direct counting. Statistical significance of differences in gene and genotype frequencies between patients and controls was evaluated for each polymorphism using Chisquare test with Yates' correction, and significance was defined as $p<0.05$.

\section{RESULTS}

\section{OPN genotype and allele frequencies}

The OPN genotype was conducted using direct sequencing of DNA fragments from the promoter regulatory region -532 to +94 in AS patients and controls. The frequency of SNP at -443 with CC homozygotes in AS patients was 0.7083 and 0.8396 in the control (Figure 1).

\section{OPN polymorphism is associated with AS susceptibility}

As shown in Table $1, T$ frequency was significantly increased in AS patients (18.75) compared to the control $(10.85, p<0.05)$, the rate of the CT+TT genotype in AS patients was significantly higher than in those with $\mathrm{CC}$ genotype compared with control $(p<0.05)$, indicating that subjects who carried T allele have a significantly higher risk of developing AS than in those with $\mathrm{C}$ allele.

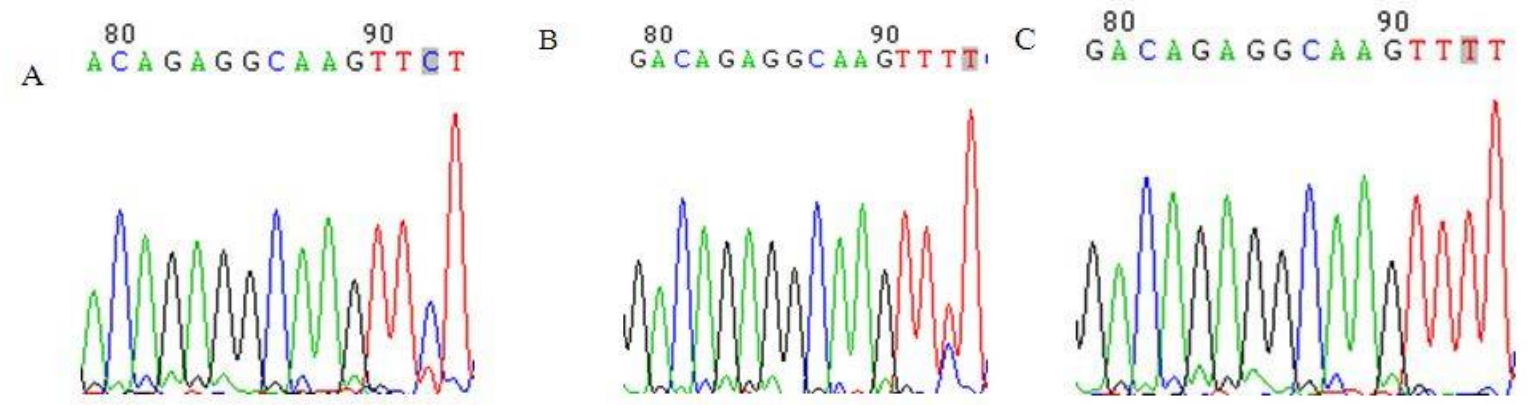

Figure 1: Schematic diagram and sequencing data of OPN. Note: $A=C / C$ homozygotes; $B=C / T$ Heterozygotes; $\mathrm{C}=\mathrm{T} / \mathrm{T}$ homozygotes 
Table 1: Allele frequency of OPN polymorphism detected in AS patients and controls

\begin{tabular}{|c|c|c|c|}
\hline Variable & AS $(n=120)$ & Control $(n=106)$ & $P$-value \\
\hline \multicolumn{4}{|c|}{ Allele, $\mathrm{n}(\%)$} \\
\hline C & 195(81.25) & 189(89.15) & \\
\hline $\mathrm{T}$ & $45(18.75)$ & $23(10.85)$ & $0.019^{1}$ \\
\hline \multicolumn{4}{|c|}{ Genotype, n(\%) } \\
\hline CC & $85(70.83)$ & $89(83.96)$ & \\
\hline CT & $25(20.83)$ & $11(10.38)$ & $0.019^{2}$ \\
\hline TT & $10(8.34)$ & $6(5.66)$ & \\
\hline
\end{tabular}

\section{DISCUSSION}

The pathogenesis of AS remains poorly understood. However, genetic factors play a significant role [23]. Single nucleotide polymorphisms (SNP) of the human OPN gene have been reported to be associated with many diseases $[24,25]$. Based on current literature, this is the first time to report the relationship between OPN polymorphism and AS patients.

In this study, we have investigated the difference in OPN gene polymorphisms between AS patients and healthy controls. The $T$ frequency was significantly increased in AS patients compared to the control $(p<0.05)$, the rate of the $\mathrm{CT}+\mathrm{TT}$ genotype in AS patients was significantly higher than those with $\mathrm{CC}$ genotype compared with the control $(p<0.05)$, indicating that subjects who carried the $T$ allele had a significantly higher risk of developing AS than those with the $\mathrm{C}$ allele. Dong et al found that the genetic variation at locus -443 of the OPN promoter plays important roles in the regulation of OPN expression and cancer progression of hepatocellular carcinoma (HCC), which is a novel determinant and target for HCC metastasis and prognosis [26]. Hao et al found that OPN -443C $>\mathrm{T}$ gene polymorphism may be used as a molecular marker to predict the treatment response to chemotherapy in advanced nonsmall-cell lung cancer patients [27]. Zhao et al found that OPN $-443 \mathrm{C} / \mathrm{T}$ polymorphism is a potential predictive marker of metastasis and poor prognosis in intrahepatic cholangiocarcinoma patients [28].

So far, genetic variants in OPN gene have been shown to be involved in susceptibility to other immune-mediated diseases such as SLE [29,30], oligoarticular juvenile idiopathic arthritis [31] and sarcoidosis [32]. Despite promising functional data, previous genotype analyses could not confirm SPP1 as significant disease modifying gene in classical Th17-mediated diseases such as multiple sclerosis [33,34] and rheumatoid arthritis [35]. However, it is first time to report the relationship between OPN polymorphism and AS patients. It is expected that this study should be confirmed in a large and ethnically divergent population in order to make a stronger conclusion about the association between -443 polymorphism with AS.

\section{Limitation of the study}

In this study, the sample size of participants was small, thus rendering the results liable to bias. Therefore, a larger-sample study needs to be undertaken.

\section{CONCLUSION}

SNP at nt -443 of the OPN gene can serve as a candidate genetic marker to evaluate the risk of AS. Subjects who carry $T$ allele may have a significantly higher risk of developing AS. This relationship is reported here for the first time.

\section{ACKNOWLEDGEMENT}

The authors thank Wei-ye Wang of Huazhong University of Science and Technology, for expert technical assistance.

\section{REFERENCES}

1. Brown MA, Wordsworth BP, Reveille JD. Genetics of ankylosing spondylitis. Clin Exp Rheumatol 2002; 20: S43-49.

2. Braun J, Sieper J. Ankylosing spondylitis. Lancet 2007; 369: 1379-1390.

3. Carette $S$, Graham $D$, Little $H$, Rubenstein J, Rosen $P$. The natural disease course of ankylosing spondylitis. Arthritis Rheum 1983; 26: 186-190.

4. Gran JT, Skomsvoll JF. The outcome of ankylosing spondylitis: a study of 100 patients. Br J Rheumatol 1997; 36: 766-771.

5. Wanders $A$, Landewé $R$, Spoorenberg A, de Vlam K, Mielants $H$, Dougados $M$, van der Linden S, van der Heijde $D$. Scoring of radiographic progression in randomised clinical trials in ankylosing spondylitis: a preference for paired reading order. Ann Rheum Dis 2004; 63: 1601-1604. 
6. Chellaiah MA, Kizer N, Biswas R, Alvarez U, StraussSchoenberger J, Rifas L, Rittling SR, Denhardt DT, Hruska KA. Osteopontin deficiency produces osteoclast dysfunction due to reduced CD44 surface expression. Mol Biol Cell 2003; 14: 173-189.

7. Ishijima M, Rittling SR, Yamashita T, Tsuji K, Kurosawa $H$, Nifuji A, Denhardt DT, Noda M. Enhancement of osteoclastic bone resorption and suppression of osteoblastic bone formation in response to reduced mechanical stress do not occur in the absence of osteopontin. J Exp Med 2001; 193: 399-404.

8. El-Tanani MK, Campbell FC, Kurisetty V, Jin D, McCann $M$, Rudland PS. The regulation and role of osteopontin in malignant transformation and cancer. Cytokine Growth Factor Rev 2006; 17: 463-474.

9. Shiraga H, Min W, VanDusen WJ, Clayman MD, Miner D, Terrell CH, Sherbotie JR, Foreman JW, Przysiecki C, Neilson EG. Inhibition of calcium oxalate crystal Growth in vitro by uropontin: another member of the aspartic acid-rich protein superfamily. Proc Natl Acad Sci U S A 1992; 89: 426-430.

10. Worcester EM, Beshensky AM. Osteopontin inhibits nucleation of calcium oxalate crystals. Ann N Y Acad Sci 1995; 760: 375-377.

11. Lieske JC, Leonard R, Toback FG. Adhesion of calcium oxalate monohydrate Crystals to renal epithelial cells is inhibited by specific anions. Am J Physiol 1995; 268: F604-612.

12. Giacopelli F, Marciano R, Pistorio A, Catarsi P, Canini S, Karsenty G, Ravazzolo R. Polymorphisms in the osteopontin promoter affect its transcriptional activity. Physiol Genomics 2004; 20: 87-96.

13. Hummelshoj $T$, Ryder LP, Madsen HO, Odum $N$, Svejgaard A. A functional polymorphism in the Eta-1 promoter is associated with allele specific binding to the transcription factor $\mathrm{Sp} 1$ and elevated gene expression. Mol Immunol 2006; 43: 980-986.

14. Hendig D, Arndt M, Szliska C, Kleesiek K, Gotting C. SPP1 promoter polymorphisms: identification of the first modifier gene for pseudoxanthoma elasticum. Clin Chem 2007; 53: 829-836.

15. Brenner D, Labreuche J, Touboul PJ, Schmidt-Petersen $K$, Poirier O, Perret C, Schonfelder J, Combadiere C, Lathrop M, Cambien F, et al. Cytokine polymorphisms associated with carotid intima-media thickness in stroke patients. Stroke 2006; 37: 16911696.

16. Naito $M$, Matsui $A$, Inao $M$, Nagoshi $S$, Nagano $M$, Ito $N$, Egashira T, Hashimoto M, Mishiro S, Mochida S, Fujiwara $K$. SNPS in the promoter region of the osteopontin gene as a marker predicting the efficacy of interferon-based therapies in patients with chronic hepatitis C. J Gastroenterol 2005; 40: 381-388.

17. Hummelshoj $T$, Ryder LP, Madsen HO, Odum $N$, Svejgaard A. A functional polymorphism in the Eta-1 promoter is associated with allele specific binding to the transcription factor $S p 1$ and elevated gene expression. Mol Immunol 2006; 43: 980-986.
18. Mochida S, Hashimoto $M$, Matsui $A$, Naito $M$, Inao $M$, Nagoshi S, Nagano M, Egashira T, Mishiro $S$, Fujiwara K. Genetic polymorphism in promoter region of osteopontin gene may be a marker reflecting hepatitis activity in chronic hepatitis $C$ patients. Biochem Biophys Res Commun 2004; 313: 10791085.

19. Hamersma J, Cardon LR, Bradbury L, Brophy S, van der Horst-Bruinsma I, Calin A, Brown MA. Is disease severity in ankylosing spondylitis genetically determined? Arthritis Rheum 2001; 44: 1396-1400.

20. Choi ST, Kim JH, Kang EJ, Lee SW, Park MC, Park YB, Lee SK. Osteopontin might be involved in bone remodeling rather than in inflammation in ankylosing spondylitis. Rheumatology (Oxford) 2008; 47: 17751779.

21. Genre F, López-Mejías R, Miranda-Filloy JA, Ubilla $B$, Carnero-López B, Gómez-Acebo I, Blanco R, Ochoa $R$, Arias-Bajo M, Rueda-Gotor J, et al. Correlation between two biomarkers of atherosclerosis, osteopontin and angiopoietin-2, in nondiabeticankylosing spondylitis patients undergoing TNF- $\alpha$ antagonist therapy. Clin Exp Rheumatol 2014; 32: 231-236.

22. World Medical Association. World Medical Association Declaration of Helsinki: Ethical Principles for Medical Research Involving Human Subjects. Seoul: From the 59th World Medical Association Assembly, October, 2008.

http://www.wma.net/en/30publications/10policies/b3/1 7c.pdf.

23. Reveille JD, Ball EJ, Khan MA. HLA-B27 and genetic predisposing factors in spondyloarthropathies. Curr Opin Rheumatol 2001; 13: 265-272.

24. Hou X, Hu Z, Huang $X$, Chen $Y$, He X, Xu H, Wang $N$. Serum osteopontin, but not OPN gene polymorphism, is associated with $\mathrm{LVH}$ in essential hypertensive patients. J Mol Med (Berl) 2014; 92: 487-495.

25. Jing M, Li B, Hou X, Shoba J, Li C, Liang H, Zhang X, Liu $E$, Yang $B$, Meng $X . O P N$ gene polymorphism and the serum OPN levels confer the susceptibility and prognosis of ischemic stroke in Chinese patients.Cell Physiol Biochem 2013; 32: 1798-1807.

26. Dong QZ, Zhang XF, Zhao Y, Jia HL, Zhou HJ, Dai C, Sun HJ, Qin $Y$, Zhang WD, Ren N, Ye QH, Qin LX. Osteopontin promoter polymorphisms at locus -443 significantly affect the metastasis and prognosis of human hepatocellular carcinoma. Hepatol 2013; 57: 1024-1034.

27. Hao Y, Liu J, Wang $P$, Wang F, Yu Z, Li M, Chen S, Ning F. OPN Polymorphism is Related to the Chemotherapy Response and Prognosis in Advanced NSCLC. Int J Genomics. 2014; 2014:846142.

28. Zhao XQ, Ma HX, Su MS, He L. Osteopontin promoter polymorphisms at locus -443 are associated with metastasis and poor prognosis of human intrahepatic cholangiocarcinoma in Chinese population. Int J Clin Exp Pathol 2014: 7: 6914-6921.

Trop J Pharm Res, December 2015; 14(12): 2322 
29. DAlfonso S, Barizzone N, Giordano M, Chiocchetti A, Magnani $C$, Castelli $L$, Indelicato $M$, Giacopelli $F$, Marchini $M$, Scorza $R$, et al. Two single-nucleotide polymorphisms in the $5^{\prime}$ and $3^{\prime}$ ends of the osteopontin gene contribute to susceptibility to systemic lupus erythematosus. Arthritis Rheum 2005; 52: 539-547.

30. Xu AP, Bai J, Lu J, Liang YY, Li JG, Lai DY, Wan X, Huang $\mathrm{HH}$. Osteopontin gene polymorphism in association with systemic lupus erythematosus in Chinese patients. Chin Med J (Engl) 2007; 120: 2124-2128.

31. Marciano R, Giacopelli $F$, Divizia MT, Gattorno $M$, Felici E, Pistorio A, Martini A, Ravazzolo R, Picco P. A polymorphic variant inside the osteopontin gene shows association with disease course in oligoarticular juvenile idiopathic arthritis. Ann Rheum Dis 2006; 65: 662-665.
32. Maver A, Medica I, Salobir B, Tercelj M, Peterlin B. Genetic variation in osteopontin gene is associated with susceptibility to sarcoidosis in Slovenian population. Dis Markers 2009; 27: 295-302.

33. Hensiek AE, Roxburgh R, Meranian M, Seaman S, Yeo $T$, Compston DA, Sawcer SJ. Osteopontin gene and clinical severity of multiple sclerosis. J Neurol 2003; 250: 943-947.

34. Mas $A$, Martínez $A$, de las Heras $V$, Bartolomé $M$, de la Concha EG, Arroyo R, Urcelay E. The 795CT polymorphism in osteopontin gene is not associated with multiple sclerosis in a Spanish population. Mult Scler 2007; 13: 250-252.

35. Urcelay E, Martínez A, Mas-Fontao A, Peris-Pertusa A, Pascual-Salcedo D, Balsa A, Fernández-Arquero $M$, dela Concha E. Osteopontin gene polymorphisms in Spanish patients with rheumatoid arthritis. J Rheumatol 2005; 32: 405-409. 